\title{
Nutritional influences on Volvariella volvacea (Bull. ex. Fr.) Sing. growth in Puerto Rico. I. Carbon and nitrogen', 2
}

\author{
Ramón I. Torres-López and Paul R. Hepperly ${ }^{3}$
}

\begin{abstract}
Laboratory tests were conducted to determine the growth of a Puerto Rican strain of the straw mushroom Volvariella volvacea on diverse carbon and nifrogen sources at variable carbon/nitrogen (c:n) ratios. Of the carbon sources (cornstarch, cellulose, maltose and lactose), cornstarch and cellulose supported the most vigorous growth. No growth was observed on lactose and maltose. Urea, sodium nitrate, peptone and casein were tested as nitrogen sources at $\mathrm{C}: \mathrm{N}$ ratios of $\infty: 1,60: 1,30: 1$ and 15:1 with cornstarch as the sole carbon source. The 60:1 C:N ratio stimulated faster growth. Nitrogen sources urea and sodium nitrate did not support growth. Organic nitrogen sources, casein and peptone, stimulated the growth of $V$, volvacea, with the faster growth on casein.
\end{abstract}

\section{INTRODUCTION}

Volvariella volvacea is the edible tropical mushroom most commonly cultivated in tropical and subtropical regions of Asia and Micronesia. Belonging to the family Plutaceae of the Basidiomycetes (15), Volvariella is the fourth most cultivated mushroom in the world $(2,3,4,5,6,10)$. In 1979, Chang estimated that the world production of Volvariella exceeded 49,000 tons (5). At harvest, nutritional value is $30 \%$ protein, $3 \%$ fat, $30 \%$ carbohydrates, $4 \%$ fibre, $9 \%$ ash, $338 \mathrm{Kcal} / 100 \mathrm{~g}$ dry weight and 206.27 $\mathrm{mg}$ vitamin $\mathrm{C} / \mathrm{g}$ dry weight (13). Straw mushrooms, rich in proteins and carbohydrates, make an excellent food. Besides supplementing human diets, mushrooms play an important role in adding variety to daily cookery because of their flavors and consistencies not found in animal or other vegetable sources. High mushroom prices make them lucrative for producers.

'Manuscript submitted to Editorial Board 30 January 1987.

2This paper is based, in part, on a thesis deposited by the senior author to the Graduate College of the University of Puerto Rico, Mayagüez Campus, in partial fulfillment of the requirements for the degree of Master in Science, Horticulture Department, College of Agricultural Sciences, 1985.

${ }^{3}$ Research Assistant in Plant Pathology, Department of Crop Protection, College of Agriculture, University of Puerto Rico and Research Plant, Pathologist, United States Department of Agriculture, Tropical Agriculture Research Station, Mayaguiez, Puerto Rico, respectively. 
Volvariella is a large pileate fungus with a dark gray cap some 8-10 $\mathrm{cm}$. in diameter. For convenience in description and discussion, the reproductive stages of the basidiocarp are divided roughly into six stages, as follows (6) (fig. 1):

1. pinhead - tiny clusters of white hyphal aggregates, where no differentiation is noticeable.

2. tiny button - spherical structure of interwoven hyphae with a slight differentiation.

3. button - spherical to ovoid structure surrounded by a layer tissue (universal veil), a longitudinal cut reveals the stipe (stalk), pileus (cap) and the lamellae (gills).

4. egg - this structure is characteristically ovoid, because of the elongation of the stipe. This is the commercially preferred stage for harvesting because of its high protein content $(+25 \%)$, best palatability and longer shelf life.

5. elongation - the stipe is is much elongated, causing the rupture of the universal veil (which now is known as the volva) revealing the stipe and a cup shaped pileus.

6. mature - the pileus is fully expanded, the gills of its lower surface become brownish-pink, and discharge of basidiospore begins.

Vegetative mycelium must be abundant and vigorous for optimum development of later reproductive stages. The vegetative stage was used exclusively in this study.

There is not much reliable information regarding the utilization of carbon, nitrogen and mineral requirements of Volvariella volvacea $(5,10)$. Before $1977(16)$, no researchers reported controlled experiments on carbon and nitrogen contents of straw mushroom substrates or what fractions of these nutrients are utilized.

\section{Carbon}

The yield of the straw mushroom on traditional substrates (rice straw, wheat straw, dry banana leaves, oil palm pericarp and sugarcane bagasse) is low (20\%). Higher yields (20 to $40 \%$ biological efficiency) have been reported on substrates that contain cotton wastes or wastes from cotton mills $(2,4,5,7,17)$. Results with these wastes containing purer and higher contents of cellulose suggest that $V$. volvacea prefers cellulose as a source of carbon for its development. Most of the cotton mill wastes contain other plant parts, making them relatively high in minerals, low molecular weight carbohydrates and nitrogen. Many researchers have used cellobiose (B-D-1,4, glucopyranosylglucose), the simplest compound having all the chemical bonds which characterize cellulose (5). Mannose 


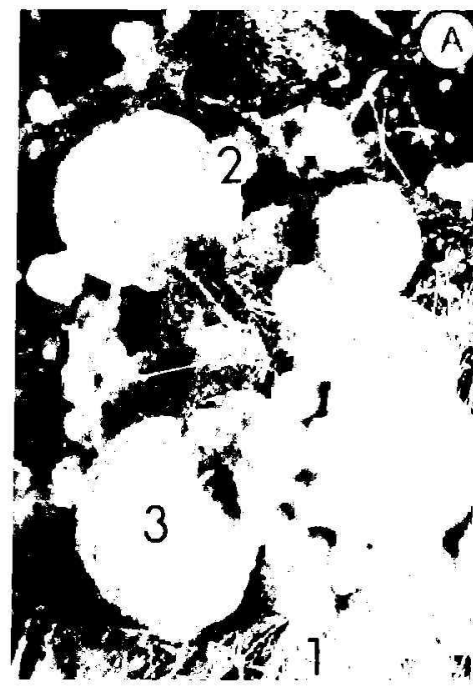

$B$
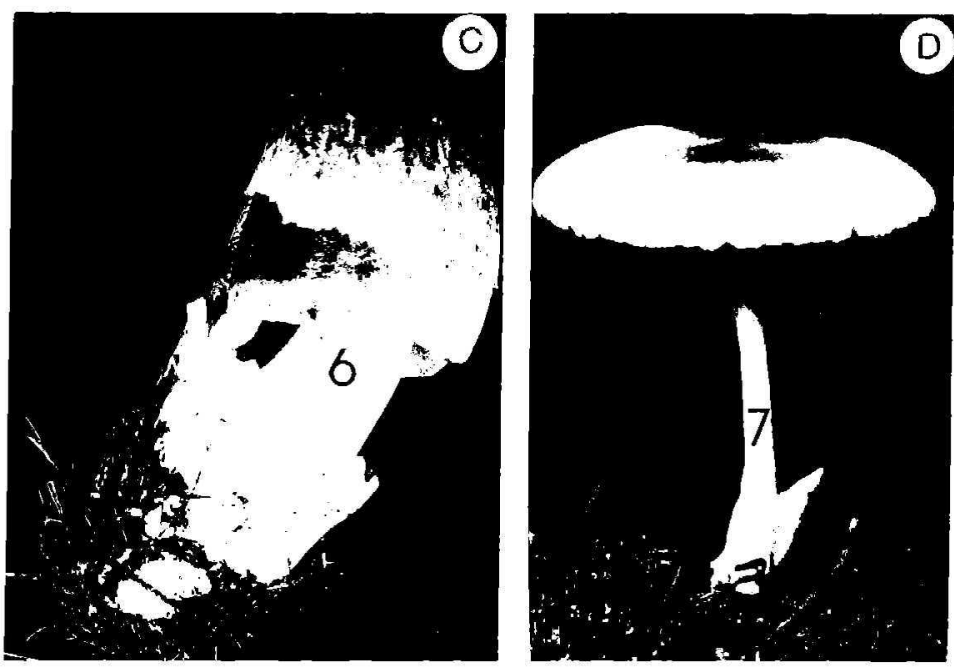

FIG. 1.-Stages of growth of $V$. volvacen's basidiocarp: A) 1) mycelium, 2) pinhead, 3) tiny button, B) 4) button, 5) egg C) 6) elongation and D) 7) mature. 
and soluble starch supported good growth of $V$. volvaced in many studies $(7,8)$. Chang-Ho et al. $(7,8)$ assayed various carbon fractions of the straw, before and after $V$. volvacea was grown on it. Of all these fractions, hemicellulose A and cellulose were the only ones showing significant decreases during straw mushroom growth. In laboratory studies, glucose and polymers of glucose support mean optimal growth, while sorbose, lactose and sucrose supported little or no growth (1). No record was found of lignin utilization by $V$. volvacea in our literature review. Cellulose is clearly the most important earbon source, and starch also is a good substrate. Puerto Rican strains of straw mushroom develop on sugarcane bagasse unlike cultivated Asian strains. No comparative studies on these strains have been reported.

\section{Nitrogen}

The final nitrogen content of $V$. volvacea is approximately $7.0 \%$ dry weight basis (12). The largest part of the nitrogen is represented by protein. A smaller portion is found in the glucosamine of the chitin and still a smaller portion in the nucleic acids. While far less nitrogen than carbon is required by $V$. volvacea, both are crucial for straw mushroom development $(5,19)$. Studies on the carbon/nitrogen (C:N) ratio reveal that $V$. volvacea has a good growth rate at a C:N ratio of $48: 1(7,8)$. Asparagine favored growth when it was used in a basal medium whose C:N ratio was 100:1 (3). Other researchers found that the best C:N ratio of the basal media was 60:1 (17). Researchers have suggested that studies in the nitrogen concentration are specific for each distinct fungus and each carbon source and nitrogen source combination. Asparagine and glutamic acid are good nitrogen sources, but best growth is usually obtained with peptone (1). Growth response to peptone and other nitrogen sources appears dependant on the straw mushroom isolate. Nitrogen concentrations recommended by various researchers are $0.25 \mathrm{~g} \mathrm{~N} /(8)$, $0.42 \mathrm{~g} \mathrm{~N} / \mathrm{(9)}, 0.47 \mathrm{~g} \mathrm{~N} / 1$ (18) and $1.32 \mathrm{~g} \mathrm{~N} /$ (3). Different basal media were used in the different publications which may help to explain differences in the data. $V$. volvacea isolates also vary.

All the studies agree that organic aminoid nitrogen, in one form or another, supports the greatest growth. They also agree that ammonium nitrate, ammonium sulfate, and urea are toxic $(3,7,8,9$ and 18).

\section{MATERIALS AND METHODS}

In 1981, a survey covering the western part of Puerto Rico was conducted to determine the incidence and distribution of edible mushrooms. Volvariella volvacea, Pleurotus spp. and Auricularia spp. are the most common native mushrooms of potential use. Our research efforts were centered on $V$. volvacea because of its rapid growth and reproductive cycle under lowland tropical conditions featuring high temperature. 
TABLs: 1.-Nitrogen sources and concentration used to study V. volvacea growth response

\begin{tabular}{lllll} 
& \multicolumn{4}{c}{ \% Nitrogen } \\
\cline { 2 - 5 } Nitrogen source & 0 & 0.75 & 1.50 & 8.0 \\
\hline Urea & 0 & 16.1 & 32.2 & 64.4 \\
Sodium nitrate & 0 & 45.5 & 91.0 & 182.0 \\
Casein & 0 & 46.9 & 93.8 & 187.6 \\
Peptone & 0 & 46.9 & 93.8 & 187.6 \\
\hline
\end{tabular}

'Grams per $100 \mathrm{mI}$ of the basic salts solution.

Isolation of pure culture and inoculum preparation

A well developed egg stage was selected because of its desirable qualities, i.e., size and high yield (2). Under aseptic conditions, a small fragment of the stipe, from a disinfected egg stage mushroom $(0.5 \%$ $\mathrm{Ca}(\mathrm{OCl})_{2}, 4 \mathrm{~min}$.) was transferced to a potato dextrose agar (PDA) culture dish. The culture was incubated at $35^{\circ} \mathrm{C}$ until the mycelium covered the surface of the media and chlamydospores were produced (18-21 days). The inoculum for the tests performed consisted of disks of PDA and mycelium obtained with a $1 \mathrm{~cm}$ cork borer, transferred to each treatment under aseptic conditions.

\section{Basic salts media}

All tests used a modification of the basic salts media reported by Khor (11). These media had all the minerals essential for supporting the growth of the fungus:4

\begin{tabular}{ll}
\multicolumn{1}{c}{ Mineral } & Molarity \\
$\mathrm{K}_{2} \mathrm{SO}_{4}$ & 0.0384 \\
$\mathrm{CaCl}_{2}$ & 0.0025 \\
$\mathrm{MnCl}_{2}$ & 0.002 \\
$\mathrm{MgSO}_{4} \cdot 7 \mathrm{H}_{2} \mathrm{O}$ & 0.002 \\
$\mathrm{NaH}_{2} \mathrm{PO}_{4} \cdot \mathrm{H}_{2} \mathrm{O}$ & 0.01 \\
$\mathrm{Na}_{2} \mathrm{HPO}_{4} \cdot 7 \mathrm{H}_{2} \mathrm{O}$ & 0.01
\end{tabular}

Nitrogen sources

V. volvacea grows naturally and commercially on substrates whose nitrogen appears in complex organic forms. To study the growth response to organic and inorganic nitrogen sources of the Puerto Rican strain, we used two sources, urea $\left(\mathrm{NH}_{2} \mathrm{CONH}_{2}\right)$ and sodium nitrate $\left(\mathrm{NaNO}_{3}\right)$, and two complex protein mixtures, casein and peptone, in $\mathrm{N}$ concentrations of $0 \%, 0.75 \%, 1.50 \%$ to $3.0 \%$ in semi-solid mineral salt solution. Cornstarch was selected as a carbon source because it stimulated the greatest mycelium growth in previous studies. C:N ratios were

‘Because of precipitation of the solution, iron was not used in preparing Khor's (11) media. 
$\infty: 1(0 \% \mathrm{~N}), 60: 1(0.75 \% \mathrm{~N}), 30: 1(1.5 \% \mathrm{~N})$ and $15: 1(3.0 \% \mathrm{~N})$ (table 1$). \mathrm{A}$ completely randomized laboratory design with 4 replicates per treatment was used. The results were confirmed by repeating the procedure once.

Sodiurn

Nitrate

Uica

Peptome

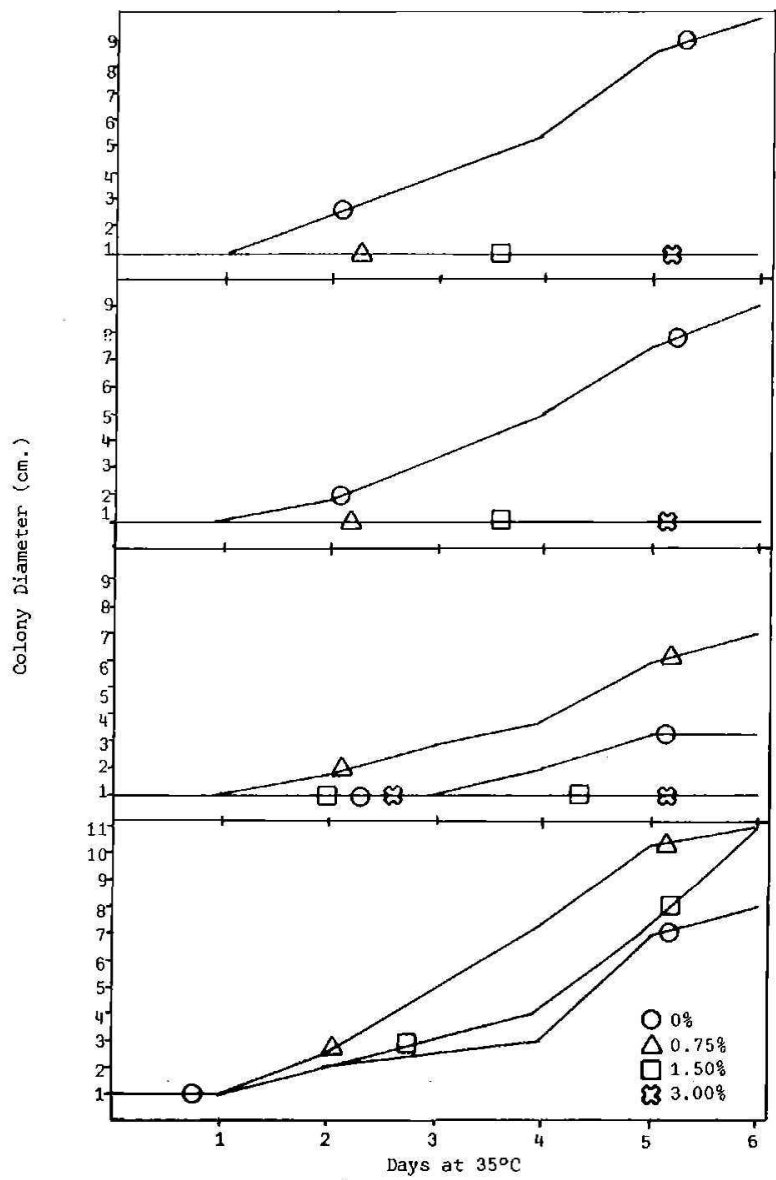

FIG. 2.-Radial mycelial growth of $V$. volvacea on 4 nitrogen sources at 4 levels of supplementation on semi-solid starch basic salt medium.'

Daily observations are the mean of 4 replications for each level of each $\mathbf{N}$-source. 
Carbon sources

After determining which nitrogen source and concentration (C:N ratio) supported the best growth of $V$. volvacea, the following carbon sources were tested: maltose and lactose (disaccharides) and cornstarch and cellulose (polysaccharides). Each of the carbon sources ( $88.2 \mathrm{~g} / \mathrm{rep}$.) was mixed with $0,3.9$ and 7.8 grams of casein/1 basic salt solution, to attain $C: N$ ratios of $\infty: 1,60: 1$ and 30:1. Sterilized solutions were poured in 15-cm sterilized petri plates and inoculated with a PDA + mycelium plug as described before. A completely randomized design with 4 replications was used. After inoculation, all plates were incubated at $35^{\circ} \mathrm{C}$. Daily measurements of colony diameter $(\mathrm{cm})$, colony vigor and surface area of the plate covered with chlamydospores were taken. Data were subjected to analysis of variance and mean separation as appropriate.

\section{RESULTS AND DISCUSSION}

Nitrogen sources

Urea and sodium nitrate did not support any growth of the Puerto Rican straw mushroom strain (fig. 2). Casein and peptone stimulated growth; up to $38 \%$ higher growth was found at $0.75 \% \mathrm{~N}$ compared to that at $0 \% \mathrm{~N}$. Peptone inhibited growth at $1.5 \%$ and $3.0 \% \mathrm{~N}$. The best results were observed in the casein treatment. The casein $0.75 \% \mathrm{~N}$ and $1.5 \% \mathrm{~N}$ treatment stimulated more growth, $30.8 \%$ and $15.2 \%$, respectively, than in the unsupplemented control. Besides the difference in colony diameter, there was a clear increase in the density and fluffiness of straw mushroom mycelium when supplemented with $0.75 \% \mathrm{~N}$.

$V$. volvacea grew best in substrates whose C:N ratios were $60: 1$ or greater. Ratios of 30:1 have a negative effect on growth, and 15:1 ratios may inhibit it totally. As in Asian strains of $V$. volvacea, our strain grew better on substrates with nitrogen of organic origin. Growth was inhibited by inorganic nitrogen. Chang-Ho (7) indicated that high levels of nitrogen can be toxic.

The greatest chlamydospore production was found on casein $0.75 \%$ $\mathrm{N}$. Peptone at $0.75 \% \mathrm{~N}$ showed good mycelial growth and chlamydospore production but less than those with casein (table 2). Our studies, like those of Voltz (18), Chadra and Purkayastha (1), and Wang (19), indicate that neither urea nor sodium nitrate stimulates growth. Organic nitrogen sources (peptone and casein) stimulate growth at C:N ratios over 50:1.

\section{Carbon sources}

Growth was stimulated by the polysaccharides (cellulose and starch) but not by the disaccharides (lactose and maltose) (table 3). Seven days after inoculation the highest C:N ratio favored the greatest mycelial growth on cellulose (table 3).

The Puerto Rican straw mushroom growth on cellulose was retarded 
TABLE 2.-Puerto Rico straw mushroom mycelial growth on 4 different nitrogen sources al 4 levels of supplementation on basal stareh and mineral salts semi-solid media

\begin{tabular}{|c|c|c|c|c|}
\hline $\begin{array}{l}\text { Nitrogen } \\
\text { source' }\end{array}$ & $\begin{array}{c}N \\
\text { Treatment }^{2}\end{array}$ & $\begin{array}{c}\text { Colony } \\
\text { diameter" }\end{array}$ & $\begin{array}{l}\text { Density of } \\
\text { mycelium }\end{array}$ & $\begin{array}{c}\text { Chlarnydospore } \\
\text { production }\end{array}$ \\
\hline & $\%$ & $c m$ & & \\
\hline \multirow{3}{*}{ Casein } & 0.0 & $8.13 \mathrm{a}^{\mathrm{b}}$ & 3 & 3 \\
\hline & 0.75 & $12.75 \mathrm{a}$ & 4 & 4 \\
\hline & 1.5 & $12.0 \mathrm{a}$ & 4 & 4 \\
\hline \multirow[t]{4}{*}{ Peptone } & 0.0 & $3.5 \mathrm{a}$ & 3 & 3 \\
\hline & 0.75 & $7.0 \mathrm{a}$ & 4 & 3 \\
\hline & 1.5 & $0.0 \mathrm{~b}$ & 0 & 0 \\
\hline & 3.0 & $0.0 \mathrm{~b}$ & 0 & 0 \\
\hline \multirow[t]{4}{*}{ Urea } & 0.0 & $8.8 \mathrm{a}$ & 3 & 2 \\
\hline & 0.75 & $0.0 \mathrm{~b}$ & 0 & 0 \\
\hline & 1.5 & $0.0 \mathrm{~b}$ & 0 & 0 \\
\hline & 3.0 & $0.0 \mathrm{~b}$ & 0 & 0 \\
\hline Sodium & 0.0 & $9.8 \mathrm{a}$ & 2 & 2 \\
\hline \multirow[t]{3}{*}{ nitrate } & 0.75 & $0.0 \mathrm{~b}$ & 0 & 0 \\
\hline & 1.5 & $0.0 \mathrm{~b}$ & 0 & 0 \\
\hline & 3.0 & $0.0 \mathrm{~b}$ & 0 & 0 \\
\hline
\end{tabular}

${ }^{2}$ Basie salt media with cornstarch as carbon source.

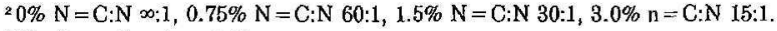

${ }^{3} \mathrm{Six}$ days after inoculation.

$11-5$ scale. 1 = thin layer of mycelium on the substrate's surface, $5=$ abundant cottony mycelium.

: $0-4$ scale. $0=0 \%$ surface area with chlamydospores, $4=100 \%$ of substrate surface covered with chlamydospores.

${ }^{6}$ Means followed by one or more letters in common do not differ significantly at the .01 probability level. (FLSD test).

and reduced compared to that on starch. Eight days after inoculation, in all the starch treatments, the mycelium totally covered the substrate surface. With starch at 7 days diameters of colonies were $54.3 \%$ larger than those with cellulose (fig. 3).

During the first 3 days after inoculation, $\mathrm{C}: \mathrm{N}$ ratio did not affect visible growth on starch. After 4 days, the 60:1 and 30:1 treatments showed the best growth. At 7 days after inoculation, $\infty: 1$ had $7.2 \%$ more growth than $60: 1$ and $30: 1$, but the 8th day, growth was the same in all treatments (fig. 3). The growth of Volvariella in starch was significantly better than in cellulose. Table 3 shows that after 7 days the highest mycelial vigor was on the starch and cellulose 60:1 and $\infty: 1$ media. Starch stimulated a faster mycelial growth and a better chlamydospore production. The starch 60:1 media showed more chlamydospores, followed by $\infty: 1$ and 30:1. Short chained carbon compounds (mono and disaccharides) did not stimulate growth of $V$. volvacea, whereas long chained polymers did. Although $V$. volvacea grew better on starch than on cellulose, utilization of cellulose is probably more important in reproductive phases. 
TABLE 3.-Mycelial growth response of $\mathrm{V}$, volvacea to different carbon sources

\begin{tabular}{lcccc}
\hline $\begin{array}{c}\text { Carbon } \\
\text { source }\end{array}$ & Treatment & $\begin{array}{c}\text { Colony } \\
\text { diameter }\end{array}$ & $\begin{array}{c}\text { Density of } \\
\text { mycelium }\end{array}$ & $\begin{array}{c}\text { Chlamydospore } \\
\text { production }^{\circ}\end{array}$ \\
\hline Cormstarch & $\infty: 1$ & $c m$ & 3 & 2 \\
& $60: 1$ & $12.9 \mathrm{c}^{6}$ & 4 & 4 \\
Cellulose & $30: 1$ & $11.7 \mathrm{c}$ & 1 & 1 \\
& $\infty: 1$ & $10.9 \mathrm{c}$ & 3 & 1 \\
& $60: 1$ & $3.4 \mathrm{~b}$ & 2 & 2 \\
Meltose & $30: 1$ & $3.9 \mathrm{~b}$ & 1 & 0 \\
& $\infty: 1$ & $3.8 \mathrm{~b}$ & 0 & 0 \\
& $60: 1$ & $1.0 \mathrm{a}$ & 0 & 0 \\
Lactose & $30: 1$ & $1.0 \mathrm{a}$ & 0 & 0 \\
& $\infty: 1$ & $1.0 \mathrm{a}$ & 0 & 0 \\
& $60: 1$ & $1.0 \mathrm{a}$ & 0 & 0 \\
\hline
\end{tabular}

'Basic salts media with casein as carbon source.

${ }^{2} \mathrm{C}: \mathrm{N}$ ratio.

${ }^{3}$ Seven days after inoculation.

$\cdot 1-5$ scale. 1 = thin layer of mycelium on the substrate's surface; 5 = abundant cottony myceilum.

${ }^{5} 0-4$ scale. $0=0 \%$ surface area with chlamydospores; $4=100 \%$ of substrate surface covered with chlamydospores.

- Means followed by one letter in common do not differ significantly at the .01 probability level (FLSD test).

\section{RESUMEN}

Cómo el carbono y el nitrógeno y la razón entre ellos afecta el crecimienta de Volvariella volvacea

Se probó la reacción de una cepa puertorriqueña de la seta china, Volvariella volvacea, a diversas fuentes de carbono y nitrógeno y la razón carbono/nitrógeno ( $\mathrm{C}: \mathrm{N}$ ) en el sustrato que estimulaba más su crecimiento. De todas las fuentes de carbono que se probaron (almidón de maíz, celulosa, lactosa y maltosa) el almidón fue el que estimuló el crecimiento más vigoroso; le seguió la celulosa. No se observó ningún crecimiento con lactosa ni maltosa. Urea, nitrato de sodio, peptona y caseína se usaron como fuente de nitrógeno con relaciones $C: N$ que variaron de $\infty_{;} 1,60: 1$, 30:1 y 15:1. La relación C:N, 60:1, estimuló mejor el crecimiento. La urea y el nitrato de sodio inhibieron el crecimiento. La caseina estimuló un crecimiento mayor y más profuso que la peptona.

\section{LITERATURE CITED}

1. Chadra, A. and R. P. Purkayastha, 1977. Physiological studies on Indian edible mushrooms. Br. Mycol. Soc. 69 (1): 63-70.

2. Chang, S. T., 1972. In: The Chinese Mushroom (Volvariella volvacea): Morphology, cytology, genetics, nutrition and cultivation. The Chinese University Press, Hong Kong. 


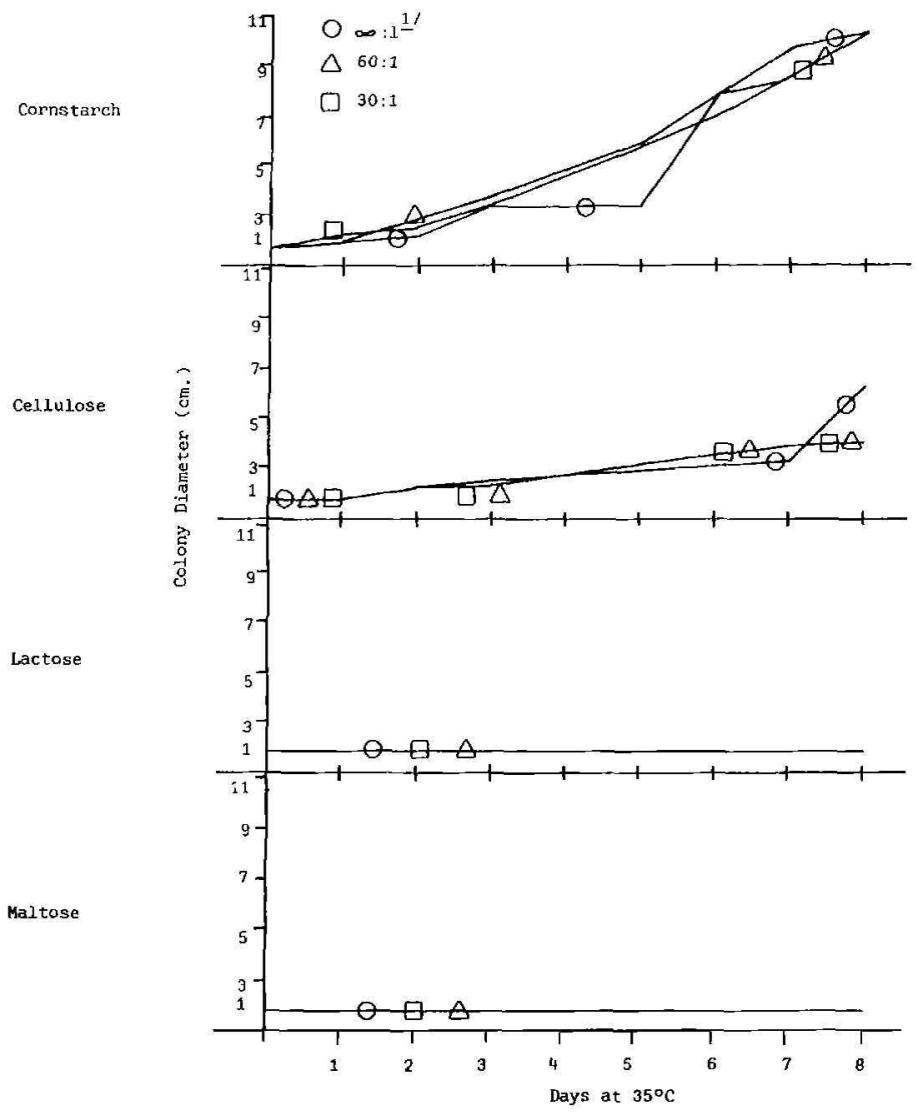

FIG. 3,-Effect of different carbon sources on the mycelial growth of $V$. volvacea.

'C:N ratio resulting from solution of different carbon source with casein as a nitrogen source.

3. - 1980. Cultivation of Volvariella mushrooms in Southeast Asia. Mushroom Newsletter for the Tropies 1 (1): 5-10.

4. - 1980. Mushroom Production in Southeast Asia. Mushroom Newsletter for the Tropies 1 (2): 18-22.

5. - 1982. Cultivation of Yolvariella mushrooms in Southeast Asia. In: Tropical Mushrooms: Biological Nature and Cultivation Methods (S. T. Chang and T. H. Quimio eds). The Chinese University Press. Hong Kong, pp. 221-65. 
6. - and C. K. Yau, 1971. Volvariella volvacea and its life history. Am. J. Bol. 58 (6): $552-61$.

7. Chang-Ho, Y., 1980. Some factors affecting cellulose utilization by Volvariella volvacea Sing. Presented at the Mycological Workshop at the York University, Toronto, Ontario. January 26, 1980.

8. — and N. T. Yee, 1977. Comparative study of the physiology of Volvariella volvacea and Coorinus cinereus. Trans. Br. Mycol. Soc. 68: 167-72.

9. Garcha, H. S. and K. L. Kalra, 1979. Paddy straw mushroom in North India. Mushroom Sci. 10 (2): 645-52.

10. Hayes, W. A., 1978. Nutrition substrates and disease control of Agaricus. In: The Biology and Cultivation of Edible Mushrooms: edited by S. T. Chang and W. A. Hayes. New York. Academic Press. pp. 219-36.

11. Khor, G. L., 1979. An investigation of the mineral requirements of Volvariella volvacea mycelium. Mushroom Sci. 10 (2): 635-44.

12. Kurtzman, R. H., Jr., 1975. Mushroom as a source of food protein. In: Protein Nutritional Quality of Foods and Feeds, edited by Friedman, Part 2. New York, Marcel Bekker. pp. 305-17.

13. Lee, T. F. and S. T. Chang, 1975. Nutritional analysis of Volvariella volvacea. $J$. Hortic. Soc. China. 21: 13-20.

14. San Antonio, J. P., P. R. Hepperly and R. L. Shaffer, 1984. Straw Mushroom in the Western Hemisphere. Mushroom Newsletter for the Tropics. 4 (4): 3-5.

15. Singer, R., 1975. The Agaricales in Modern Taxonomy. J. Cramer, Vaduz, Gerrnany.

16. Turner, E. M., 1977. Enzyme activity of Agaricus bisporrus in compost. In: Aston Seminar-2. Edited by W. A. Hayes, England, Maney and Sons, Ltd.

17. Tzeng, D. S., 1974. Studies on the nutritional requirements and the improvement of techniques in cultivation of straw mushroom Volvariella volvacea. M. S. Thesis. Dep. Plant Pathol., Nath. Chung Hsing, Univ. Taichung, Taiwan.

18. Voltz, P, A., 1972. Nutritional studies on species and mutants of Lepista, Canlharellus, Pleurolus and Volvariella. Mycopathol. Mycol. Appl. 48: 175-85.

19. Wang, C. W., 1979. Celluloytic enzymes of Volvariella volvacea. In: Tropical Mushroom: Biological Nature and Cultivation Methods. S. T. Chang and T. H. Quimio (Eds). The Chinese University Press, Hong Kong. 